Stanley N. Katz

\title{
SCHOLARS AND TEACHERS: HIDDEN PARTNERS FOR HIDDEN COLLECTIONS
}

ExPosing Hidden Collections is very close to my heart because I was originally trained as an historian, an early American historian; and in doing both my undergraduate work and my graduate work, I was from the start a manuscript historian. I would guess that 90 percent of the materials I used in writing my dissertation were manuscript materials. So I have been at this a long time, and working with archivists and with rare books and special collections librarians all along. I did my undergraduate thesis in the Houghton Library at Harvard, which was presided over by an efficient and terrifying woman named Elizabeth Jackman, whom I will never forget. Those were back in the days when you were only allowed to use a pencil Ms. Jackman had approved in order to take your notes. These were well cataloged and obvious collections I was using; nevertheless, I got my hands dirty as a researcher in that way and I discovered the joys and the excitement of working with manuscript materials.

That was even more true when I did my dissertation research in London, where I spent almost every day in the British Library, what was then the British Museum, in the Manuscripts Room. I read manuscripts every day for a year there and in the Public Records Office. One story from that time really highlights for me what we are talking about. I was interested in the relationship between New York politics in the eighteenth century and British politics, but there were some personal connections I couldn't track down. So I found my way to the Historical Manuscripts Commission Office, which was presided over by an incredibly wonderful woman named Elizabeth Coates. We had tea-that's how you started a relationship in England-and I then described to her my project of trying to find connections between the Delancey family in New York, a prominent political family, and certain English political families. The name Delancey didn't mean anything to her, but she said, "Tell me more about it," so I described some of the relationships. 
The office was not very large, but it contained manuscript catalogs of historical collections from all over England. Ms. Coates wandered into the next room, filled floor to ceiling with row upon row of finding aids, reached up to the third shelf, and produced a volume of the finding aid to the Lincolnshire archives. She started to flip through it, said "There!" and she sent me off to Lincoln. I am not going to tell the whole story, but I confess that the only real archival discovery I've made in my whole life was made at the Lincolnshire Archives Committee in Exchequer Gate, Lincoln, and I never would have found it, even with the finding aid, if not for Miss Coates and her command of those manuscript guides. That's part of my message to you.

The second thing I would like to mention is that I have used manuscripts and other special collections not only in my research, but also in my teaching. I was part of a group at the University of Wisconsin in the late 1960s that developed the Wisconsin Laboratory Course in American History, now taught all over the country. The idea is that students could-and shouldlearn history through the use of primary sources. In the course of an entire year, our students never read a secondary source. One freshman unit that we developed concerned a Wisconsin Fourierite community whose papers were held at the State Historical Society in their Manuscripts Collections. Some undergraduate students even helped to process these collections. I can assure you it was an unforgettable learning experience for those students, some of whom I still hear from more than thirty years later. And it would not have happened but for the sympathetic understanding of the teaching project by Gerald Hamm, then the state archivist.

Thus, my orientation toward this problem is both as a researcher and as a teacher. Here I want to make a plea that is uncharacteristic for me. It is this: Please continue to think of scholars and teachers as your primary user audience and think only secondarily of "everybody in the world," the public audiences that now have access to our scholarly research resources through the Web. I think there is a real danger of losing sight of who our effective audience is and of what we need to do to serve them adequately. For in trying to do too much for too many, we risk not doing enough for our most crucial user communities.

I have a basic orientation that is reflected in parts of the white paperperfection is the enemy of the good. I don't care about perfect finding aids of any kind. We need metadata, we need good metadata, but we only need them because we care primarily about data. Making it pos- 
sible to locate and use the data is the obligation of those of us who care about these collections. I recognize that is going to require trade-offs. We ought to be prepared to make trade-offs, and we need to be clearer and more systematic about them than we have been.

I think that there is, indeed, a white elephant in our closet of collections. That elephant is the entire digital environment. It is tempting to think that all of our problems are going to be transformed by digitization in one form or another. You have never met a scholar who is a greater advocate of digital scholarship and digitization than I am. But I am here to say that digitization will only do some things and to argue that none of us will live to see a time when anything like a significant minority of our research data is converted to digital form. That means that we will continue to be responsible for the preservation and use of these materials for a good many generations before the Era of Significant Digitization comes round, assuming, as I do not, that will ever occur. That is simply to say that we must put digitization into historical (and future) perspective.

My overall reaction to the white paper, which I generally found to be an extremely interesting and helpful document, is that it is very much a document written by a committee. Although it is very nicely put together, I think it is apparent to the uninitiated (that's me) that there are real tensions among those who drafted it. Some of the recommendations do not appear to fit with the first parts of the document. I think the framers need a deeper agreement on the direction in which they hope to proceed. Yogi Berra famously said, "If you don't know where you're going, you can't get there." The notion of a national collaborative plan is extremely interesting, but most of the fundamental problems are local. The core institutions are local, and I have much greater concern about getting it right at the local level than I have for vast schemes, which have a way, in my experience, of not happening.

Robert Merton, who just died last year, taught us about the midlevel hypothesis, and I think that midlevel approaches are exactly what we need to consider as we worry about hidden collections. The white paper distinguished between processed and unprocessed collections. I understand what that means, but, in fact, a great many collections are-and should be-partially processed. It is worth thinking about "partially processed" as a formal category. In fact, we probably need a range of options between processed and unprocessed in order to systematize our realistic objectives and capacities. Whether figuring out the hierarchy of priori- 
ties within any institution or on a more collaborative basis, it seems to me that the realistic potential for use has to be the criterion according to which categories are made and decisions are formulated. How are these things likely to be used? Indeed, are they likely to be used at all? We must always remember that the materials we now hold that currently seem unpromising may be precisely the most valuable scholarly materials fifty or one hundred years from now. These are tough decisions, but they are the decisions we have to make.

I feel this way particularly about metadata. There is no greater enthusiast for EAD than I am. But we don't need everything up to that standard. As we plan allocations for descriptive materials, we will have to think systematically again about midlevel, or partial, descriptive options. What is it we can afford to do that will make these things available in a pretty good way without striving to achieve perfection? And, again, we must focus on potential users. Users who have no idea what is in a collection obviously need a lot of help. But what proportion of your users are, instead, highly expert and have a pretty good idea of the kinds of information that are to be found? Surely, perfect finding aids would be wonderful, and these expert users would be grateful for them, but they are not absolutely essential, and it is the absolutely essential that we should worry about first.

And, by the way, the report at one point criticizes analog and local finding aids in a way that I find troubling. Think back to my Ms. Coates story. Those of us who are specialized scholars know what we are looking for when we go to repositories. We frequently know the repositories. All repositories have some handwritten cards and primitive finding aids that are nevertheless absolutely invaluable to experienced researchers. God bless them. Hang on to them because they're still of use, even though I am sure not advocating creating new primitive finding aids (or retaining old card catalogs).

But what is most important to me, and I will try to focus on that now, is a double theme that I have tried to sound over the past twenty years. The first theme is the importance of the scholar-librarian in the special collections area. I think the scholar-librarian has never been more obviously an appropriate model for special collections than now. I made that argument fifteen years ago in a conference at Houghton Library, and I want to make it again. The kind of assistance I got in the UK in the 1950s was absolutely invaluable. I couldn't have done the work that I did were I not actually collaborating with librarians and archivists. 
I still remember individuals who were indispensable to me. As special collections move into the digital environment, that genre of librarybased scholarship becomes even more important because of the various problems of authority, confusion, and overabundance of information that require not just technological expertise, but scholarly knowledge and approach. I fear that this has not been sufficiently recognized.

The library community spends a lot of time talking about the training of librarians and archivists. That discussion is evolving and beginning to move, in my view, in the right direction. Obviously, competence in technology is an essential part of such training. Most of us here did not take up the technology until we were quite mature, and it will be different (better) for younger people. But I think there are also new combinations of experiences and expertise coming into play. The environment we live in is not digital or analog; it's both. These things have to interdigitate (ouch!), and we haven't done enough thinking about how we would possibly do that. We need competent technologists as well as traditional library and archival skills, but the future managers will have to be considerably more than a combination of the two. We need a new breed of librarians that we are only just beginning to conceptualize.

My second theme is the new environment for teaching. Of course, we are now using digital resources to teach, but even more important is that we also are using other kinds of traditional special collections in ways that we have seldom done before. This goes back to the experiments we were making at Wisconsin thirty years ago. At that time, Ernie Boyer was the U.S. Commissioner of Education (it wasn't a department yet), and we were responding to his request that the humanities and social sciences think about uses for the "discovery method" of teaching science in a laboratory approach. And that is exactly what we did. We tried to build on the use of a wide variety of objects and artifacts in order to enable students to perform a sort of humanities experiment with the objects before coming to conclusions about them. That is why we didn't want them reading secondary works. We wanted their self-formulated opinions, not the opinions of somebody else.

This sort of teaching has now become commonplace. This is because cognitive psychology, which really began in midcentury, has now triumphed as a way of thinking about teaching; and people like Lee Schulman at the Carnegie Foundation, Howard Gardner at Harvard, and others have shown us how to proceed toward "active" learning, or as Howard calls 
it, "learning for understanding." (I am proud, by the way, of the fact that Howard was a student in the first freshman seminar I gave at Harvard, the first in which I used only primary manuscript materials.) In any case, this is the basis for what we are doing: The combination of the availability of source materials in digital forms and the focus on active learning based on real-life experimentation with research data. This emerging conjunction provides an entirely new environment in which there is no longer a distinction between scholarship and teaching. And special collections are likely to be one of the crucial sites for this process to take place.

Think of the most important databases that are currently used for teaching. One of the best in my field is Ed Ayers's Valley of the Shadow, created at the University of Virginia. You can do important research on the Civil War using this database, and it is also one of the best electronic databases for teaching nineteenth-century American history. Valley of the Shadow was created in a library. It was done as a collaboration among librarians, technologists, and scholars; and that is one of the things that makes it a harbinger of the future in archives, teaching, and scholarship.

Let me say that I believe that the greatest failure of scholarly libraries in my lifetime is that they have not enlisted the active participation of scholars in planning, administration, and decision-making. Correspondingly, the greatest failure of the scholarly community has been its failure to engage the libraries and the librarians. Of course, we encounter little examples of cooperation here and there. For instance, at Princeton we have had a series of spectacular history bibliographers with Ph.D.s in history, and we have just chosen a new one, with a Yale Ph.D. in Medieval Studies, at Firestone Library. Or, to give another example, we all know about the close library collaboration with the handful of scholars who really care about library things and who generally base themselves in libraries. This works in the following way: I care about libraries. I care about what gets acquired. I make friends with the librarians and archivists who make those decisions. I get what I want. Right? But "I" am not most people, and I believe that we are moving into an environment in which such decisions need to be made openly, jointly, and systematically.

In the first years of my presidency at ACLS, I worked closely with Jim Haas and the Council on Library Resources to establish a national committee that brought together librarians and archivists and administrators and scholars. That went on more or less successfully for a few years and then faded away when Jim retired. So far as I know, no such mecha- 
nism has replaced our committee. We have to find new ways of achieving high-level communication and, ideally coordination, but, here again, I think we have to begin the process at the local level. I would urge you to create such cross-sectoral mechanisms on your own campus Begin to train the scholars to understand the emerging nature of the academic library and permit the scholars to begin to train you to understand what they are currently up to in their research-and teaching.

Finally, I want to say that I think that in addition to the sort of big, essentially library and archival things that the white paper suggests, I would urge you to think about some new approaches, partly as a way of building the kinds of collaborations that I think are absolutely essential. Consider, for example, what Pat Battin tried to do when we were working on the great brittle books projects. We at ACLS helped her recruit scholars for the committees to decide what ought to be filmed and preserved. That was a very basic, but absolutely essential, step. However, we did not find a way to follow the project up, and then it withered away. There are few existing mechanisms for sustained and meaningful collaboration between scholars and libraries. We need to find ways to create and sustain a level of engagement that will make libraries and scholars a seamless web.

I can give a trivial example out of my own experience of one way in which librarians train scholars. I got a call from our public administration librarian at Firestone Library, the late and great Rosemary Little, because I was one of the few faculty members who used her legal materials. She said, "I need a morning from you," so I went over and I asked, "What's the problem?" She said, "Well, we're beginning to move into remote storage." I said, "Okay, so what am I supposed to do about that?" "Well," she said, "I've got to get rid of 200 shelf feet of materials in the next three months." And I said, "Well, that ought to be feasible." She said, "It is feasible. You've got till noon to tell me what goes." And I did. Not a very major example of what we can do, and probably not even a good idea, but she certainly got my attention with respect to the kinds of important decisions that librarians have to make.

What I would propose that you consider as you contemplate the white paper is a series of three to six topical scholarly teaching projects. I don't much care what, precisely, the projects are. My field is American history. I'll use that as an example, but they could be in science or in absolutely anything that your collections pertain to. These would be projects in which technologists, librarians and archivists, scholars, and different kinds 
of scholars and teachers, even people who aren't primarily scholars, but primarily teachers, would come together to think about structuring a major project all the way from acquiring materials, through processing them and using them in particular ways. One can easily imagine, for example, a project on immigration in American history. It wouldn't affect all libraries, just those with relevant collections. Some of the thinking would be a little like what went into the Making of America experience some years ago. But I can imagine how to do a project like that, that would bring people together around subjects that were of intense professional and personal interest to them, and that would enable us to think through and feel our way through actually collaborating across these lines.

So let me conclude by simply making a plea. Don't forget the scholars. Don't forget the teachers. We are your primary users. We are not, but we should be, your primary advocates. You have some hard work to do in order to make us your advocates and collaborators, and unless we work together, the promised land of library-based research and teaching in the digital era will be long in coming. I would hope that in thinking about the hidden collections problem, you would also think about your hidden partners - the scholars and teachers. 